\title{
Cytokine production in patients with inflammatory bowel disease
}

\author{
M Nakamura, H Saito, J Kasanuki, Y Tamura, S Yoshida
}

\begin{abstract}
The production of cytokines in peripheral blood mononuclear leukocytes of patients with inflammatory bowel disease was investigated. $\mathbf{T}$ cell subset analysis and differential white blood cell counts were also performed. Thirty five patients with ulcerative colitis, 14 with Crohn's disease, and 15 age matched healthy volunteers were studied. No differences were observed in $T$ cell subsets and OKT4/OKT8 ratios in patients with ulcerative colitis or Crohn's disease compared with controls. Interleukin $1 \beta$ production was significantly increased in active ulcerative colitis and Crohn's disease, compared with values in controls, but returned to control levels in the inactive stages. In addition, in active ulcerative colitis and Crohn's disease, there were significant correlations between the interleukin $1 \beta$ production and the ulcerative colitis activity index or Crohn's disease activity index. Interleukin 2 production was also signifcantly increased in the active ulcerative colitis and significantly correlated to the activity index, but there was no change in Crohn's disease patients compared with controls. Gamma interferon production in patients was the same as that in controls. This study suggests that the interleukin $1 \beta$ and 2 values in peripheral mononuclear leukocytes of active untreated inflammatory bowel disease are indicators of the disease states of ulcerative colitis or Crohn's disease, or both.
\end{abstract}

Cytokines play important roles in the immune inflammatory reaction. Much attention has recently been directed to the roles of these cytokines in inflammatory bowel disease. There are several reports of abnormal cytokine production in inflammatory bowel disease - for example the upregulation of interleukin 1 production, ${ }^{\prime}$ and reduced ${ }^{2}$ or normal ${ }^{3}$ secretion of interleukin 2 . In addition, gamma interferon production has been shown to be impaired ${ }^{45}$ or unchanged. ${ }^{6}$ Although these cytokines have been considered to play. a crucial role in inflammatory bowel disease, the potency of mononuclear leukocytes in inducing these mediators has not yet been completely determined.

It is generally accepted that in the cytokine cascade interleukin 1 is produced in macrophages and monocytes and in turn promotes the induction of interleukin 2,7 which stimulates gamma inferferon production in $\mathrm{T}$ cells. ${ }^{8}$ Gamma interferon has inducing effects on interleukin 1 secretion in monocytes. ${ }^{9}$ Based on these studies, we compared the production of inter- leukin 1, interleukin 2, and gamma interferon in peripheral blood mononuclear leukocytes obtained from patients in the active or inactive stages of ulcerative colitis and Crohn's disease. We also searched for a correlation between cytokine production and inflammatory bowel disease activity.

\section{Methods}

REAGENTS

RPMI 1640 and fetal calf serum (FCS) were purchased from Grand Island Biological Company (NY, USA). Concanavalin A (con A) was purchased from Sigma Chemical Company (St Louis, MO, USA). OKT4 or OKT8 monoclonal antibodies were obtained from Ortho Diagnostic Systems Inc (Raritan, NJ, USA). ELISA kits for measuring interleukin $1 \beta$ were obtained from Otsuka Assay Laboratory (Tokushima, Japan). Interleukin 2 radioimmunoassay kits were from Amersham International plc (Amersham, Bucks, UK) and gamma interferon radioimmunoassay kits were from Centocor Inc (Malvern, PA, USA).

\section{PATIENTS}

Thirty five Japanese patients with ulcerative colitis (23 men and 12 women, mean (SD) age $27.5(17.5)$ years), 14 patients with Crohn's disease (12 men and 2 women, mean (SD) age $20.4(13.2)$ years), and 15 healthy age matched volunteers (10 men and 5 women, mean (SD) age $25 \cdot 6(12 \cdot 5)$ years) were studied. Eleven patients (4 women and 7 men, aged 20-54 years) had a variety of non-malignant conditions. Two patients had diverticular disease, six patients had infectious enteritis, and three had irritable bowel disease. The ulcerative colitis activity index (UCAI) $^{10}$ was used to assess disease activity (Table I). The maximum index of the UCAI is $100 \%$; we defined active disease as a UCAI of $20 \%$. The Crohn's disease activity index (CDAI)" was used to determine activity in this disorder: a CDAI of over 150 was taken to indicate active disease. The patients' medical treatments at the time the assays were performed are listed in Table II.

\section{PREPARATION OF MONONUCLEAR LEUKOCYTES} Mononuclear leukocytes were collected from citrated peripheral blood by Ficoll-Paque gradient centrifugation ( $400 \mathrm{~g}$ for $\mathbf{3 0}$ minutes at room temperature) and washed twice with phosphate buffered saline (PBS) without calcium and magnesium (PBS(-)). 
TABLE I Ulcerative colitis activity index (UCAI)

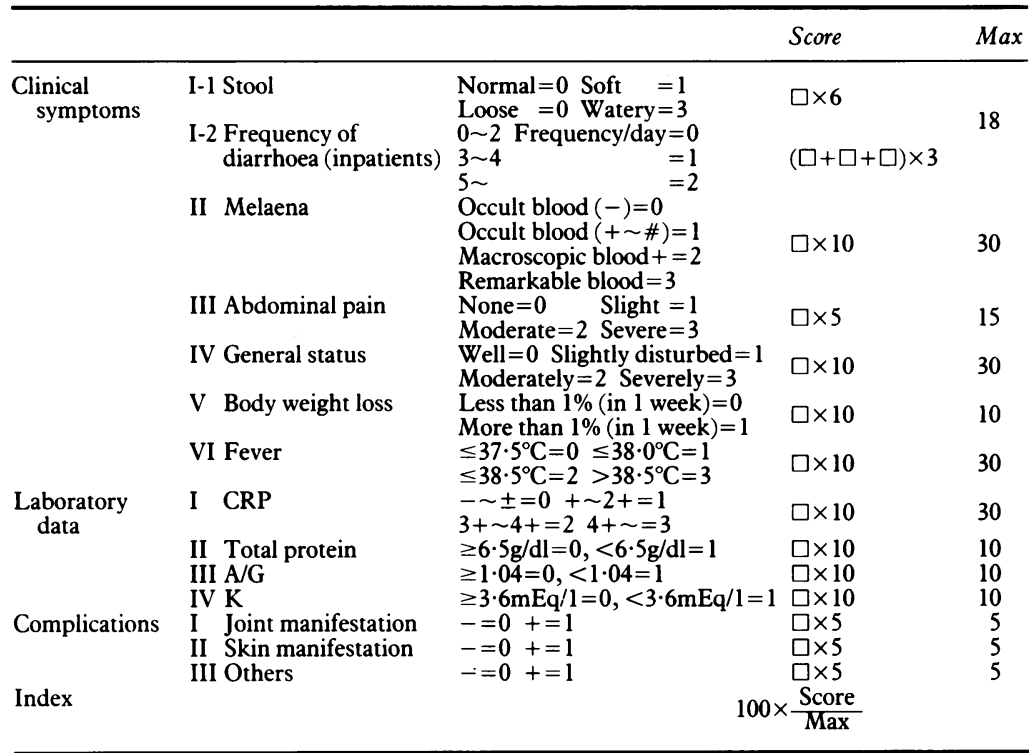

\section{PRODUCTION OF CYTOKINES}

Mononuclear leukocytes were suspended in culture medium RPMI 1640 containing 5\% FCS, $40 \mu \mathrm{g} / \mathrm{ml}$ gentamycin, and $7 \cdot 5 \mu \mathrm{g} / \mathrm{ml}$ con $\mathrm{A}$, at a concentration of $2 \times 10^{6}$ cells $/ \mathrm{ml}$, and $250 \mu \mathrm{l}$ of the cell suspension were put into each well of a 96 well microculture plate (Corning, USA, round bottomed). Cells were incubated for 24 hours in $5 \% \mathrm{CO}_{2} 95 \%$ air at $37^{\circ} \mathrm{C}$, and then the supernatant was collected and stored at $-70^{\circ} \mathrm{C}$ until assayed. We also performed differential white blood cell counts and $T$ cell subset analyses of mononuclear leukocytes from patients both in the active and inactive stages of ulcerative colitis and Crohn's disease. Each experiment was performed in duplicate.

\section{ASSAY OF INTERLEUKIN $1 \beta$ AND 2 AND GAMMA INTERFERON}

Levels of each cytokine in the culture supernatants were directly assayed using the appropriate ELISA or radioimmunoassay. Assays were performed in duplicate according to the manufacturers' instructions. Sample cytokine concentrations were determined from the standard curve obtained using the standards supplied with the kits. The sensitivity of each RIA was $15 \cdot 6-500 \mathrm{pg} / \mathrm{ml}$ for interleukin $1 \beta, 10$ $500 \mathrm{pg} / \mathrm{ml}$ for interleukin 2, and $0 \cdot 1-50 \mathrm{u} / \mathrm{ml}$ for gamma interferon. Data are given as mean (SD).

\section{T CELL SUBSET ANALYSIS}

$T$ cell subsets were analysed by indirect fluorescent staining using OKT4 or OKT8 monoclonal

TABLE II Medical treatments in patients with ulcerative colitis and Crohn's disease

\begin{tabular}{lll}
\hline & $\begin{array}{l}\text { Ulcerative } \\
\text { colitis }\end{array}$ & $\begin{array}{l}\text { Crohn's } \\
\text { disease }\end{array}$ \\
\hline Corticosteroids & 2 & 3 \\
Sulphasalazine & 6 & 2 \\
Corticosteroids +sulphasalazine & 7 & 3 \\
Sulphasalazine+6 MP & 1 & 0 \\
No medication & 1 & 2 \\
\hline
\end{tabular}

$6 \mathrm{MP}=6$-Mercaptopurine antibody. Briefly, $50 \mu \mathrm{l}$ of whole blood were mixed with FITC labelled OKT4 or OKT8 monoclonal antibody appropriately diluted in $50 \mu \mathrm{l} \mathrm{PBS}(-)$ and was incubated for 30 minutes at $4^{\circ} \mathrm{C}$. Red blood cells were lysed by $0.82 \%$ $\mathrm{NH}_{4} \mathrm{Cl}$ (final concentration) by incubation for 15 minutes at room temperature. $T$ cell subsets were determined by a laser flow cytometer (FCM-1, Japan Spectroscopic Co Ltd, Tokyo, Japan).

\section{STATISTICS}

Statistical significance was determined using either the non-paired or paired Student's $t$ test unless otherwise stated. Linear regression analysis between cytokine production and the UCAI or CDAI was carried out using the commercially available static software STAX.

\section{Results}

\section{INTERLEUKIN $1 \beta$ PRODUCTION}

In mononuclear leukocytes obtained from patients in the active stages of ulcerative colitis and Crohn's disease, interleukin $1 \beta$ production was significantly increased compared with values in controls (controls, $912.9(364.0) \mathrm{pg} / \mathrm{ml}$ : active ulcerative colitis, 1950.7 (1471) $\mathrm{pg} / \mathrm{ml}, \mathrm{p}<0.01$ : active Crohn's disease, $2445 \cdot 4(1508) \mathrm{pg} / \mathrm{ml}$, $\mathrm{p}<0.01$ ). In addition, interleukin $1 \beta$ production reverted to control levels in inactive disease, as shown in Figure 1. In paired patients, interleukin $1 \beta$ production in the active stages of ulcerative colitis and Crohn's disease was significantly greater than in inactive disease (Fig 1).

\section{INTERLEUKIN 2 PRODUCTION}

Interleukin 2 production in mononuclear leukocytes was significantly increased in ulcerative

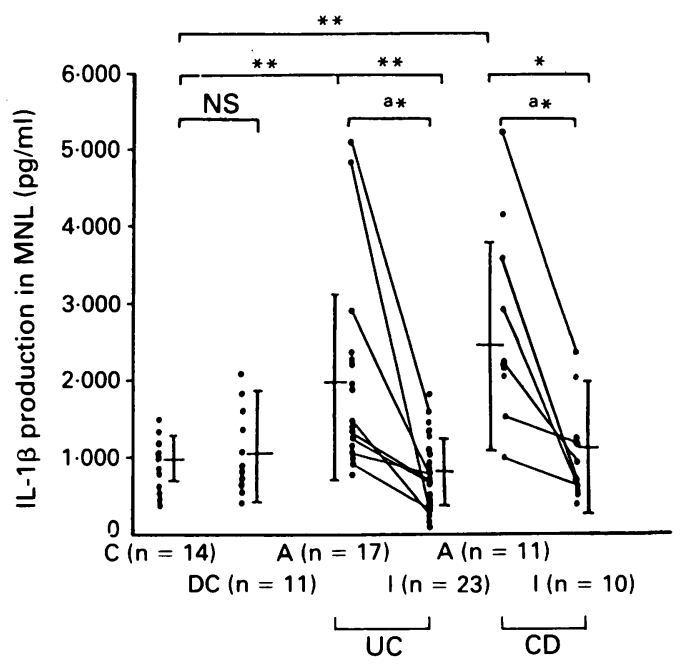

Figure 1: Comparison of interleukin $1 \beta(I L-1 \beta)$ production in mononuclear leukocytes (MNL) obtained from patients with inflammatory bowel disease. MNL $\left(2 \times 10^{6} \mathrm{cells} / \mathrm{ml}\right)$ were inflammatory bowel disease. MNL $\left(2 \times 10^{6}\right.$ cells $\left./ \mathrm{ml}\right)$ were
stimulated with $7.5 \mu \mathrm{g} / \mathrm{ml}$ concanavalin $A$ for 24 hours at $37^{\circ} \mathrm{C}$ in $5 \% \mathrm{CO}_{2} 95 \%$ air. Number of subjects is shown in parentheses. Vertical bars represent mean $(S D) . D C=$ disease control; $C=$ control subjects; $A=$ active stage $I=$ inactive stage. ${ }^{\star} p<0.05,{ }^{\star \star} p<0.01,{ }^{a}{ }^{\star} p<0.05$ (comparison in paired patients). 


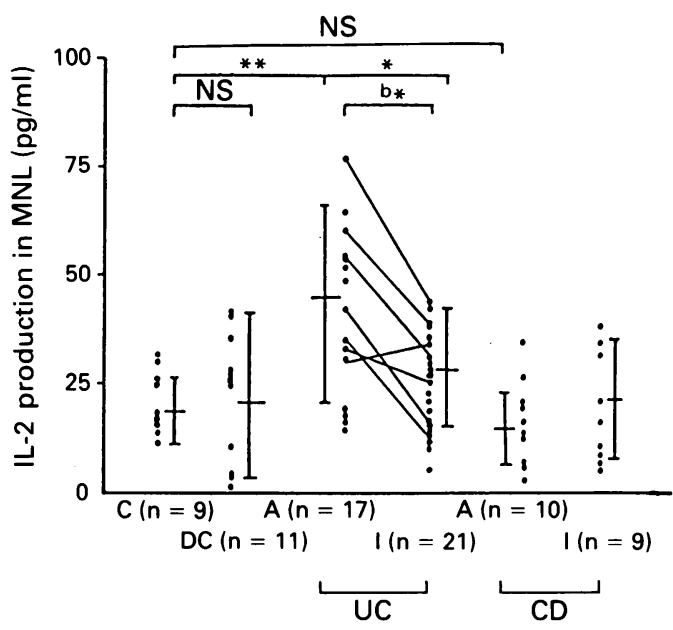

Figure 2: Comparison of interleukin $2(I L-2)$ production in mononuclear leukocytes (MNL) obtained from patients with inflammatory bowel disease. Experimental conditions were the same as in Figure 1. Number of subjects is shown in parentheses. Vertical bars represent mean $(S D) .{ }^{\star} p<0.05$ ${ }_{\star \star \star} p<0.01,{ }^{b} p<0.05$ (comparison in paired patients).

colitis patients with active disease compared with controls and also reverted to control levels in quiescent disease (control, $18.6(7.0) \mathrm{pg} / \mathrm{ml}$ : active ulcerative colitis, $43 \cdot 1(20 \cdot 6) \mathrm{pg} / \mathrm{ml}$, $\mathrm{p}<0.01$ : inactive ulcerative colitis, $27.5(14.6)$ $\mathrm{pg} / \mathrm{ml}, \mathrm{p}<0.05)$. Interleukin 2 production in Crohn's disease patients with both active and inactive disease, however, was the same as that of controls (Fig 2). In paired patients, interleukin 2 production was also significantly increased in the active compared with inactive ulcerative colitis (Fig 2).

\section{GAMMA INTERFERON PRODUCTION}

Gamma interferon production was unchanged compared with controls, both in active and quiescent ulcerative colitis and Crohn's disease (Fig 3).

CORRELATION BETWEEN CYTOKINE PRODUCTION AND UCAI OR CDAI

In untreated patients with active ulcerative

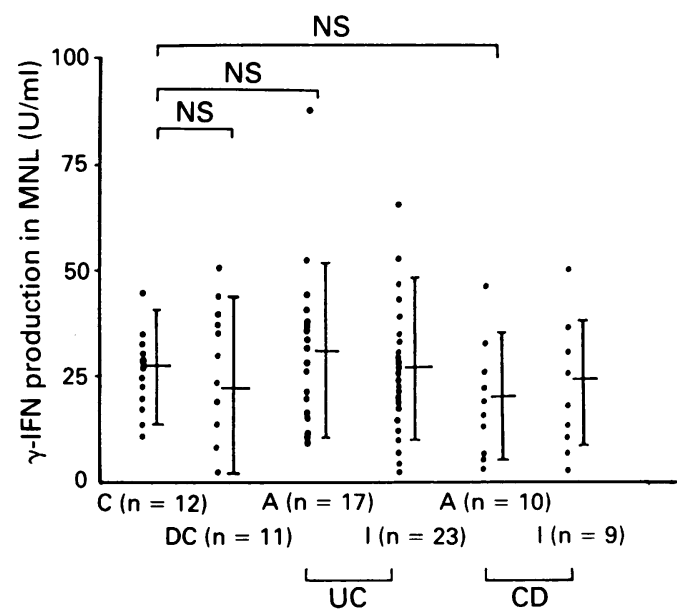

Figure 3: Comparison of gamma interferon $(\gamma-I F N)$ production in mononuclear leukocytes $(M N L)$ obtained from production in mononuclear leukocytes (MNL) obtained fron patients with inflammatory bowel disease. Experimental given in parentheses. Vertical bars represent mean $(S D)$. colitis and Crohn's disease, there were significant correlations between the interleukin $1 \beta$ production and the UCAI $(r=0.67, p<0.05)$ or CDAI $(\mathrm{r}=0.88, \mathrm{p}<0.05)$. A significant correlation was also observed between interleukin 2 production and UCAI in the active stage of ulcerative colitis $(\mathrm{r}=0.68, \mathrm{p}<0.05)($ Fig 4$)$.

\section{DIFFERENTIAL WHITE BLOOD CELL COUNT}

The white blood count in active ulcerative colitis and Crohn's disease was significantly higher than in controls (controls, 5857 (814) ml: active ulcerative colitis, $8884(2763) \mathrm{ml}, \mathrm{p}<0.05$ : active Crohn's disease, 9718 (2560) ml, $\mathrm{p}<0.05)$ White blood counts reverted to control values in quiescent ulcerative colitis and Crohn's disease. The proportion of monocytes in mononuclear leukocytes in active ulcerative colitis and Crohn's disease was significantly higher than in control subjects (control, 5.1 (1.4)\%: active ulcerative colitis, $7.4(5.4) \%, \mathrm{p}<0.05$ : active Crohn's disease, $7 \cdot 1(5.8) \%, \mathrm{p}<0.05)$ and reverted to control values in inactive disease. Eosinocytes were significantly increased in both the active and inactive stages of ulcerative colitis and Crohn's disease (Fig 5).

\section{T CELL SUBSET ANALYSIS}

In active and inactive ulcerative colitis and Crohn's disease, no differences were seen in the proportions of $\mathrm{T}$ cells expressing OKT4 and OKT 8 compared with control values. The ratios of OKT4 to OKT8 were also the same as in control subjects (Table III).

\section{Discussion}

We obtained evidence that interleukin $1 \beta$ production in mononuclear leukocytes was significantly increased in patients with active Crohn's disease. Satsangi et al ${ }^{12}$ also reported that there was a tendency toward increased interleukin $1 \beta$ production in mononuclear leukocytes obtained from subjects with active Crohn's disease. New findings in the present study are that interleukin $1 \beta$ production was also significantly increased in patients with active ulcerative colitis. Of great interest is that there are significant correlations between interleukin $1 \beta$ production and the UCAI or CDAI. To our knowledge this is the first report suggesting that interleukin $1 \beta$ production in peripheral mononuclear leukocytes is an indicator of disease activity in ulcerative colitis and Crohn's disease. Our results strongly support the proposal of other workers ${ }^{12}$ that the increased interleukin $1 \beta$ production plays an important role in the development of inflammatory bowel disease. Mahida $e t$ al' reported that mononuclear leukocytes isolated from colonic

\begin{tabular}{|c|c|c|c|c|}
\hline Study group & & OKT4(\%) & OKT8(\%) & $T 4 / T 8$ \\
\hline $\begin{array}{l}\text { Ulcerative } \\
\text { colitis } \\
\text { Crohn's } \\
\text { disease } \\
\text { Control }\end{array}$ & $\left\{\begin{array}{l}\text { Active } \\
\text { Inactive } \\
\text { Active } \\
\text { Inactive }\end{array}\right.$ & $\begin{array}{l}41 \cdot 1(14 \cdot 7) \\
39 \cdot 7(12 \cdot 1) \\
42 \cdot 8(16 \cdot 2) \\
39 \cdot 3(15 \cdot 2) \\
40 \cdot 0(15 \cdot 5)\end{array}$ & $\begin{array}{l}28.2(13 \cdot 2) \\
33.1(12.5) \\
27.1(11 \cdot 4) \\
25 \cdot 3(14 \cdot 3) \\
30.5(13.5)\end{array}$ & $\begin{array}{l}1.45(0.8) \\
1.20(0.7) \\
1.58(0.9) \\
1.55(0.8) \\
1.31(0.8)\end{array}$ \\
\hline
\end{tabular}



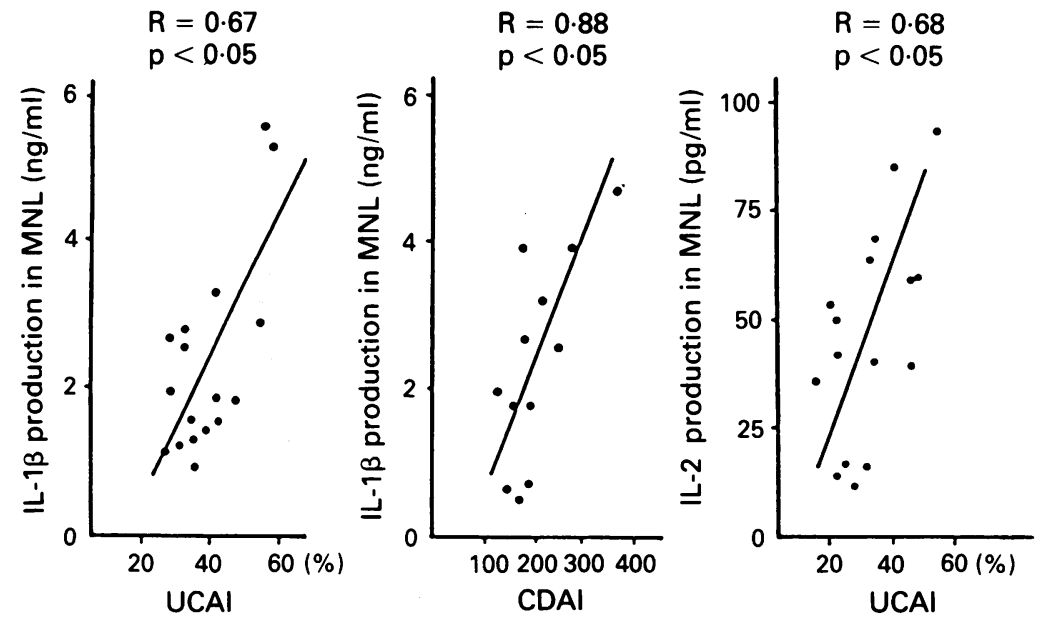

Figure 4: Correlation between cytokine production and UCAI or CDAI. Cytokine production in the active stage was compared with the disease activity index.

mucosa with inflammatory bowel disease produced a significantly greater amount of interleukin $1 \beta$. They speculated that the major source of interleukin $1 \beta$ was macrophages in mononuclear leukocytes. Recently Suzuki et $a l^{13}$ reported that interleukin $1 \beta$ production in peripheral blood monocytes was significantly increased in inflammatory bowel disease patients. The present study showed that the proportion of monocytes in peripheral mononuclear leukocytes was significantly increased in patients in the active stages of ulcerative colitis and Crohn's disease. Taken collectively, therefore, monocytes in mononuclear leukocytes seem to have abnormally enhanced interleukin $1 \beta$ production in active ulcerative colitis and Crohn's disease.

The potency of interleukin $1 \beta$ production reverted to control level in the inactive stages of ulcerative colitis and Crohn's disease. The monocyte proportion in mononuclear leukocytes

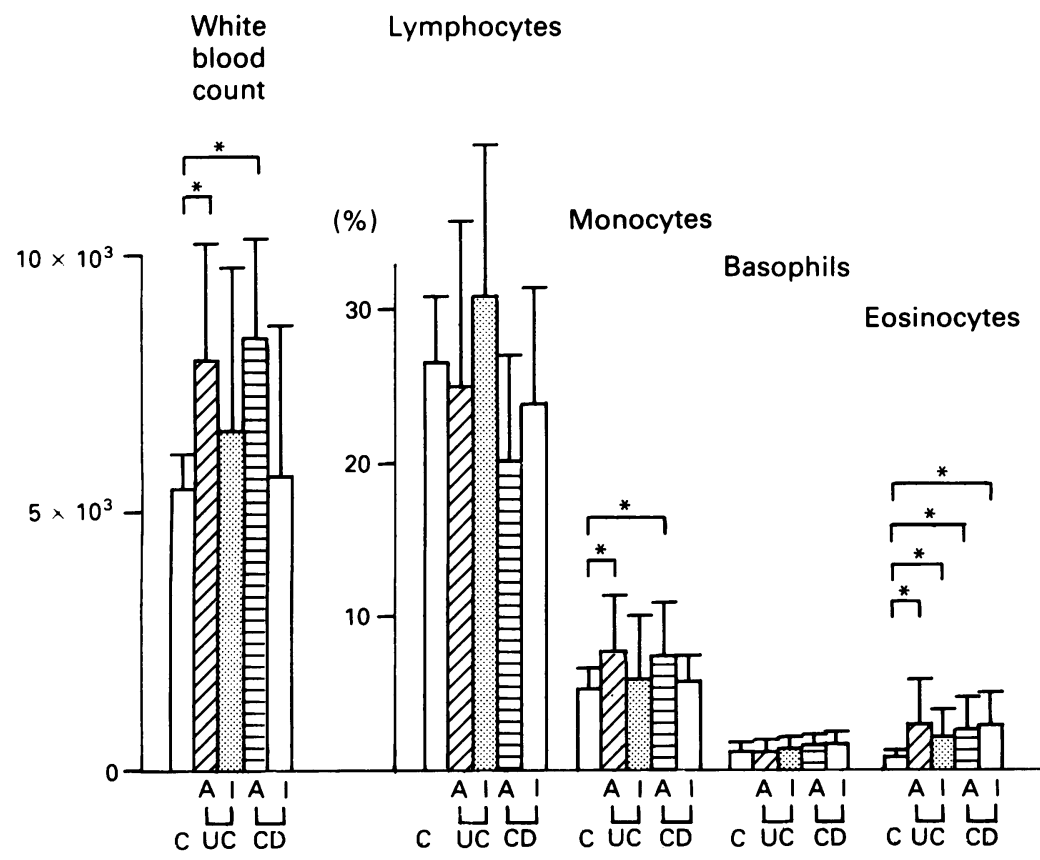

Figure 5: Differential white blood cell count in inflammatory bowel disease patients. Vertical bars represent mean $(S D)$ of 10 subjects. ${ }^{\star} p<0.05 . A=$ active and $I=$ inactive disease; $C=$ control $; U C=$ ulcerative colitis $; C D=C$ rohn's disease . was significantly increased in the active stage and was the same as control levels in the inactive stage. We prescribed corticosteroids for these patients and blood samples were taken during or just after steroid therapy. As other investigators found that corticosteroids inhibited interleukin 1 production, ${ }^{14}$ the reduction in interleukin $1 \beta$ production can be partly ascribed to steroid therapy and/or partly due to the resultant decrease of monocytes in mononuclear leukocytes.

Interleukin 2 production in mononuclear leukocytes was also significantly increased in ulcerative colitis patients and reverted to control values in the inactive stage. This finding parallels the changes in interleukin $1 \beta$ production between active and inactive ulcerative colitis and seems to support the close relationship between interleukin $1 \beta$ and interleukin 2 , as previously reported. ${ }^{7}$ The present study also showed, for the first time, a significant correlation between interleukin 2 production and the UCAI, indicating that interleukin 2 production may also reflect disease activity in ulcerative colitis. The finding that interleukin 2 production in patients with inactive ulcerative colitis and Crohn's disease was the same as that in controls is consistent with the data of Ming et $a l,{ }^{3}$ who found that interleukin 2 production in peripheral mononuclear leukocytes of inflammatory bowel disease patients (including ulcerative colitis and Crohn's disease in remission) was not changed compared with control values.

A noteworthy finding was that interleukin 2 production in active Crohn's disease was not changed, although interleukin $1 \beta$ production was significantly increased. Recently, several investigators noted that a soluble interleukin 2 receptor was increased in blood and peripheral mononuclear leukocyte culture medium during active Crohn's disease. ${ }^{1516}$ The insignificant change in interleukin 2 production may be the result of a concomitant increase in interleukin 2 receptor production and trapping of free interleukin 2 in the culture medium as suggested by Mueller et $a l .{ }^{15}$ Another possibility is that this defect in peripheral mononuclear leukocytes mirrors the events occurring in the intestinal mucosa. Thus migration of upregulated $\mathrm{T}$ cells into the mucosa may deplete peripheral mononuclear leukocytes of interleukin 2 producing cells. The amount of interleukin 2 detected in the culture medium represents a dynamic balance between the production and absorption of interleukin 2 by $T$ cells expressing the interleukin 2 receptor. ${ }^{17}$ Therefore it is also possible that the non-significant level of interleukin 2 in the culture medium of mononuclear leukocytes from active Crohn's disease indicates increased absorption of interleukin 2 .

Gamma interferon production in ulcerative colitis and Crohn's disease was not changed compared with control values. The same result was observed by Bass et al,${ }^{6}$ who noted normal in vitro gamma interferon production in peripheral mononuclear leukocytes from ulcerative colitis and Crohn's disease patients. Gamma interferon production reportedly depends directly on the amount of induced interleukin $2 .^{8}$ However, the present study failed to show further enhance- 
ment of gamma interferon production in ulcerative colitis patients, in whom interleukin 2 production was significantly increased. These data may indicate some dysfunction of the cascade reaction in producing interleukin 2 and gamma interferon in ulcerative colitis patients, as has also been alluded to by other investigators. $^{1819}$ Contrary to the present data, Mutchnick et $a l^{+}$reported impaired gamma interferon production in peripheral mononuclear leukocytes of Crohn's disease and untreated ulcerative colitis patients. In addition, Miura and Hiwatashis found a decrease in gamma interferon production in peripheral mononuclear leukocytes of Crohn's disease and normal production in ulcerative colitis. We found no significant differences in $\mathrm{T}$ cell subsets and the OKT4/OKT8 ratio, in agreement with the data reported by Mutchnick $e t a l^{4}$ and Miura and Hiwatashi. ${ }^{5}$ Therefore, the discrepancy is not likely to be due to the difference in the number of gamma interferon producing cells. The discrepancy of cell incubation time and stimulants used may partly explain the differences.

The present study indicates that the production of interleukin $1 \beta$ and interleukin 2 in peripheral mononuclear leukocytes reflects to some extent the disease activity of ulcerative colitis and Crohn's disease. The present results also showed that there is some dysfunctional difference in the cytokine cascade between ulcerative colitis and Crohn's disease. However, the lymphocyte population of the mucosal layer may significantly differ from that of the peripheral blood. Thus, it is not clear whether similar dysfunctions in lymphokine production occur in intestinal mucosal mononuclear leukocytes.

1 Mahida YR, Wu K, Jewell DP. Enhanced production of interleukin- $1 \beta$ by mononuclear cells isolated from mucosa with active ulcerative colitis and Crohn's disease. Gut 1989 30: 835-8

2 Fiocchi C, Hilfiker ML, Youngman KR, Doerder NC, Fink $\mathrm{JH}$. Interleukin 2 activity of human intestinal mucosa mononuclear cells. Decreased levels in inflammatory bowel disease. Gastroenterology 1984; 86: $734-42$.

3 Ming RH, Atluru D, Spellman CW, Imir T, Goodwin JS, Strickland RG. Peripheral blood mononuclear cell interleukin-2 production, receptor generation and lymphokineactivated cytotoxicity in inflammatory bowel disease. $\mathcal{F}$ Clin Immunol 1987; 7: 59-63.

4 Mutchnick MG, Lee HH, Hollander DI, Haynes GD, Chua DC. Defective in vitro gamma interferon production and elevated serum immunoreactive thymosin B4 levels in patients with inflammatory bowel disease. Clin Immunol Immunopharm 1988; 47: 84-92.

5 Miura M, Hiwatashi N. Cytokine production in inflammatory bowel disease. 7 Clin Lab Immunol 1985; 18: 81-6.

6 Bass D, Levin S, Hahn T, Matot E, Katzat I, Becker S, et al. The interferon (IFN) system and NK activity in ulcerative colitis (UC) and Crohn's disease (CD) [Abstract]. Gastrocoliterology 1983; 84: 1099.

7 Dinarello CA. Interleukin 1. Rev Infect Dis 1984; 6: 51-95.

8 Kasahara T, Hooks JJ, Dougherty SF, Oppenheim JJ. Interleukin 2-mediated immune interferon (IFN- $\gamma$ ) production by human $\mathrm{T}$ cells and T cell subsets. $\mathcal{F}$ Immunol 1983; 130: 1784-9.

9 Arenzana-Seisdedos F, Virelizier JL, Fiers W. Interferons as macrophages-activating factors. III. Preferential effects of interferon- $\gamma$ on the interleukin 1 secretory potential of fresh aged human monocytes. F Immunol 1985; 134: 2444-8.

10 Yoshikawa N, Kasanuki J, Imaizumi T, Koseki H, Kaneko R, Suzuki Y, et al. Ulcerative colitis activity index (UCAI). 12th International Congress of Gastroenterology. Lisbon, Portugal, 1984; 12: (Abstract) 85 .

11 Best WB, Becktel JM, Singleton JW, Kern F. Development of a Crohn's disease activity index. National Cooperative Crohn's Disease Study. Gastroenterology 1976; 70: 439-44.

12 Satsangi J, Wolstencroft RA, Cason J, Ainley CC, Dumonde DC, Thompson RPH. Interleukin 1 in Crohn's disease. Clin Exp Immunol 1987; 67: 594-605.

13 Suzuki Y, Tobin A, Quinn D, Whelan A, O'Morain CA. Production of interleukin 1 by highly purified monocytes in inflammatory bowel disease. Eur $\mathcal{F}$ Gastroenterol Hepatol 1991; 3: 45-9.

14 Snyder DS, Unanue ER. Corticosteroids inhibit murine macrophage Ia expression and interleukin 1 production. macrophage la expression an $1982 ; 129$ : 1803-5.

15 Mueller CH Konotion in Crohn's disease. Increased levels of soluble interleukin-2 receptor in serum and in supernatants of stimulated perireceptor in serum and in supernatants of stimulated peripheral bis. 46 .

16 Crabtree JE, Juby LD, Lobo AJ, Bullimore DW, Axon ATR. Soluble interleukin-2 receptor in Crohn's disease: relation of serum concentrations to disease activity. Gut 1990;31: 1033-6.

17 Bonnard R, Yasaka K, Jacobson D. Ligand-activated T cell growth factor-induced proliferation: absorption of $\mathrm{T}$ cell growth factor by activated T cells. I Immunol 1979; 123: 2704-8.

18 Auer IO, Roder A, Frohlich J. Immune status in Crohn's disease. VI. Immunoregulation evaluated by multiple, distinct T-suppressor cell assays of lymphocyte prodistinct T-suppressor cell assays of lymphocyte proliferation, and by enumeration of immunoregulatory

19 James SP, Neckers LM, Graeff AS, Cossman J, Balch CM, Strober W. Suppression of immunoglobulin synthesis by lymphocyte subpopulations in patients with Crohn's disease. Gastroenterology 1984; 86: 1510-8. 